\title{
PRELIMINARY PHYTOCHEMICAL SCREENING AND EVALUATION OF MUSCLE RELAXANT ACTIVITY OF ETHANOLIC EXTRACT OF RHIZOME OF ZINGIBEROFFICINALE
}

\author{
JURI DAS*, DIPANKAR SAHA \\ Girijananda Chowdhury Institute of Pharmaceutical Science, Azara, Ghy 781017 \\ Email: jurid24@gmail.com
}

Received: 21 May 2017, Revised and Accepted: 22 Jul 2017

\begin{abstract}
Objective: The aim of this study to investigate the Preliminary Phytochemical Screening and evaluation of Muscle relaxant activity of ethanolic extract of Zingiberofficinale (EEZO) belonging to the family Zingiberaceae using Swiss albino mice in comparison with that of standard drug (Lorazepam).

Methods: The phytochemical screening of the EEZO was done as per the standard methods. Then the extract was evaluated for its muscle relaxant activity compared with Control which is Normal saline $(0.9 \% \mathrm{NaCl}$ solution) at a dose of $10 \mathrm{ml} / \mathrm{kg}$ and standard drug Lorazepam at a dose of 10 $\mathrm{mg} / \mathrm{kg}$ p. o by using Rota-rod apparatus. Twenty mice were taken of either sex and are divided into four groups and each group contains five animals. The first group was considered as control, the second group considered as standard and the third and fourth group received extracts (EEZO) at a dose of $100 \mathrm{mg} / \mathrm{kg}$ and $200 \mathrm{mg} / \mathrm{kg}$ p. o respectively. All the preparations were administered orally.
\end{abstract}

Results: The Preliminary Phytochemical screening of Ethanolic plant extract of Zingiberofficinale showed the presence of alkaloids, Carbohydrates, phlobotannins, flavonoids, glycosides, saponins, tannin and terpenoids and absence of steroids. The two doses of EEZO i.e. $100 \mathrm{mg} / \mathrm{kg}(7.8 \pm 0.421$ sec) and $200 \mathrm{mg} / \mathrm{kg}(3.07 \pm 0.385)$ significantly reduced the fall of time in the Rota-rod apparatus as compared to control (48.67 \pm 1.112$)$ with $\mathrm{p}$ value $<0.0001$. The result is quite satisfying when compared with the standard drug i.e. $10 \mathrm{mg} / \mathrm{kg}$ p. o. (6.2 \pm 0.331 ).

Conclusion: The result of the given study demonstrated that the ethanolic extract of Zingiber officinale is having Dose Dependent Muscle Relaxant activity.

Keywords: Zingiberofficinale, Rota-rod apparatus, Lorazepam, Muscle relaxant activity

(C) 2017 The Authors. Published by Innovare Academic Sciences Pvt Ltd. This is an open access article under the CC BY license (http://creativecommons.org/licenses/by/4.0/) DOI: http://dx.doi.org/10.22159/ijcpr.2017v9i5.22129

\section{INTRODUCTION}

Herbal medicines, also known as herbalism or botanical medicine, is a medical system based on the use of plants or plant extracts that may be eaten or applied to the skin. Since ancient times, herbal medicines has been used by many different cultures throughout the world to treat illness and to assist bodily functions. Herbal remedies in the form of extracts, tinctures, capsules and tablets as well as teas may be recommended by healthcare practitioners of many different disciplines as a practical way to address a wide variety of medical conditions [1]. Herbal medicine is the mainstay of about $75-80 \%$ of the world's population, mainly in developing countries, for primary health care because of better cultural acceptability, better compatibility with the human body and lesser side effects [2].

These plants have rich resources of ingredients which can be used in drug development and synthesis. Besides that, these plants play a critical role in the development of human cultures around the whole world. Moreover, some plants consider as an important source of nutrition and as a result of that these plants recommended for their therapeutic values. These plants include ginger, green tea, walnuts and some other plants [3].

Zingiberofficinale is a flowering plant whose rhizome (underground stem), ginger root or simply ginger is widely used as a spice or a folk medicine. It is a herbaceous perennial which grows annual stems about a meter tall bearing narrow green leaves and yellow to red flowers which belonging to the family Zingiberaceae and is a common condiment for various foods and beverages [4]. It is widely used around the world wide in foods as a spice. It is possibly native to India, widely grown as a commercial crop in south and Southeast Asia, tropical Africa, Latin America Caribbean and Australia [5-6].

A muscle relaxant is a drug that affects skeletal muscle function and decreases the muscle tone. It may be used to alleviate symptoms such as muscle spasms, pain etc. The term "muscle relaxant" is used to refer to two major therapeutic groups: neuromuscular blockers and spasmolytic. Neuromuscular blockers act by interfering with transmission at the neuromuscular end plate and have no central nervous system (CNS) activity. They are often used during surgical procedures and in intensive care and emergency medicine to cause temporary paralysis. Spasmolytic, also known as "centrally acting" muscle relaxants, are used to alleviate musculoskeletal pain and spasms and to reduce spasticity in a variety of neurological conditions. While both neuromuscular blockers and spasmolytic are often grouped together as muscle relaxants, the term is commonly used to refer to spasmolytic only [7-8].

\section{MATERIALS AND METHODS}

\section{Collection of plant material}

The ginger was collected from the local market of Dhaligaon (Bongaigaon), Dist-chirang, India. The plant specimen was authenticated by Dr. Partha Pratim Baruah, HOD, Department of Botany, Gauhati University, Assam. A voucher specimen has been deposited in the Herbarium of the Department of Botany, Gauhati University with Acc. No.-18220 for future references.

\section{Chemicals and reagents required}

Petroleum ether, Ethanol, Dragondroff reagent, Mayer's reagent, Wagner's reagent, Molish's reagent, Fehling solution A and B, sulphuric acid, lead acetate, sodium citrate, copper sulphate, ferric chloride, sodium hydroxide, glacial acetic acid, benzene, chloroform, ammonia, nitric acid, potassium nitrite, hydrochloric acid. All the chemicals and solvents used were of standard analytical grades.

\section{Preparation of extract of Zingiber officinale}

The extraction of dried rhizome of Zingiberofficinale was done by successive extraction procedure. It was carried out by using petroleum ether $(95 \% \mathrm{~V} / \mathrm{V})$ by soxhlet apparatus. The solvent 
(about $300 \mathrm{ml}$ ) was added to a round bottom flask, which is attached to a sox let extractor and condenser on a heating mantle. The crushed plant material was loaded into the thimble, which is placed inside the sox let extractor. The side arm is lagged with glass wool. The solvent is heated using the heating mantle and will begin to evaporate, moving through the apparatus to the condenser. The condensate then drips into the reservoir containing the thimble. Once the level of solvent reaches the siphon it pours back into the flask and the cycle begins again. The process should run for a total of $12 \mathrm{~h}$. After that, the second solvent i.e. ethanol was used in the extraction process and the process is repeated for $16 \mathrm{~h}$ to get the extract. Finally, the extracts were kept in a Petri dish and cover it in air tight condition. Thus by using petroleum ether and ethanol the extraction of the rhizome of Zingiberofficinale was done. The percent yield of ethanolic extract was then calculated out.

\section{Phytochemical screening}

The freshly prepared ethanolic extract of the rhizome of Zingiberofficinale (EEZO) was subjected to various preliminary phytochemical tests to detect its phytoconstituents. All the tests were done using standard method.

\section{Pharmacological study}

\section{Drugs and chemicals}

Lorazepam (as standard drug)-10 mg/kg, Normal saline $(0.9 \%$ $\mathrm{NaCl}$ solution)-10 ml/kg and chemical 5\% CMC were used during the experimental study. The extract was suspended in distilled water and CMC and then subjected for muscle relaxant activity using Rota rod apparatus. All the preparations were administered orally (p. o).

\section{Experimental animals and toxicity study}

Swiss albino mice aged 8-10 w (weighing 25-30 gm.) of either sex were used for this study. The approval for this study will be taken from the Animal Ethics Committee of Girijananda Chowdhury Institute of Pharmaceutical Science, Guwahati, Assam.

\section{[Approval No.: GIPS/IAEC/B. Ph/2017/13]}

The acute oral toxicity study will be performed as per OECD guideline 423. The animals will be acclimatized to laboratory conditions for one week prior to the experiment. The temperature in the animal house will be maintained at $25 \pm 2{ }^{\circ} \mathrm{C}$ with relative humidity of $30-70 \%$

\section{Acute toxicity study}

According to the literature survey, the safety profile of Zingiberofficinale was evaluated by acute and sub chronic toxicity study of the ethanolic extract of ZO rhizome (NECI) in Swiss albino mice. In acute toxicity study, the extract of ZO up to $2000 \mathrm{mg} / \mathrm{kg}$ body wt. did not produce any toxic effect or death. So, therefore, it indicated that the rhizome of Zingiberofficinale is safe in Swiss albino mice demonstrating no noticeable toxicity [9].

\section{Muscle relaxant activity}

The muscle relaxant activity of ethanolic extract of Zingiberofficinale will be tested in mice (25-30 gm.) by using Rota rod apparatus taking Lorazepam as standard drug.

\section{Rota-rod apparatus}

The Rota-rod apparatus consists of a metal rod $(3 \mathrm{~cm}$ diameter) coated with rubber attached to a motor with the speed adjusted to 2 rotations per minute. The rod is $75 \mathrm{~cm}$ in length and is divided into 6 sections by metallic discs, allowing the simultaneous testing of 6 mice. The rod is in a height of about $50 \mathrm{~cm}$ above the tabletop in order to discourage the animals from jumping off the roller. Cages below the section serve to restrict the movements of the animals when they fall from the roller [10].

In this method, twenty mice were divided into four groups having five animals in each group. Here the groups are:

Group I-Control (Normal saline- $10 \mathrm{ml} / \mathrm{kg}$ )

Group II-Standard (Lorazepam- $10 \mathrm{mg} / \mathrm{kg}$ )

Group III-Extract (EEZO), Test I: $100 \mathrm{mg} / \mathrm{kg}$

Group IV-Extract (EEZO), Test II: $200 \mathrm{mg} / \mathrm{kg}$

Here, Group, I served as control which received Normal saline $10 \mathrm{ml} / \mathrm{kg}$; Group II served as a standard drug which received Lorazepam $10 \mathrm{mg} / \mathrm{kg}$, p. o.; Group III and Group IV received the ethanolic extract of Zingiberofficinale orally at a dose of 100 and $200 \mathrm{mg} / \mathrm{kg}$ respectively.

Animals remain on the Rota-rod apparatus at a speed of $25 \mathrm{rpm}$ for 5 min or more after low successive trials are included in the study. After the administration of control, standard and extracts, the "fall off Time" from the rotating rod were noted. The difference in the fall of time from the rotating rod between the control and the treated mice was taken as an index of Muscle relaxation.

\section{Statistical analysis}

The results were expressed as mean \pm SD. Statistical analysis was carried out by using Graphpad prism trial version software. $P$ values $<0.05$ were considered significant.

\section{RESULTS}

\section{Phytochemical screening of ethanolic extract of rhizome of Zingiber officinale}

Phytochemical screening of Ethanolic plant extract of Zingiberofficinale showed the presence of alkaloids, Carbohydrates, phlobotannins, flavonoids, glycosides, saponins, tannin and terpenoids and absence of steroids.

The observations of phytochemical constituents found in EEZO are presented in table 1.

\section{Muscle relaxant activity}

The muscle relaxant activity of EEZO using Rota-rod apparatus in mice is presented in table 2 :

Table 1: Phytochemical screening of EEZO

\begin{tabular}{lll}
\hline S. No. & Phytochemical tests & Ethanolic extracts of zingiberofficinale \\
\hline 1 & Alkaloids & $+\mathrm{ve}$ \\
2 & Carbohydrates & $+\mathrm{ve}$ \\
3 & Tannins & $+\mathrm{ve}$ \\
4 & Glycosides & $+\mathrm{ve}$ \\
5 & Saponins & $+\mathrm{ve}$ \\
6 & Steroids & $-\mathrm{ve}$ \\
7 & Flavonoids & $+\mathrm{ve}$ \\
8 & Terpenoids & $+\mathrm{ve}$ \\
9 & Phlobotannins & $+\mathrm{ve}$ \\
\hline
\end{tabular}

Key: +ve=Present,-ve=absent 
Table 2: Muscle relaxant activity by using rota rod method in mice

\begin{tabular}{lllll}
\hline Group & Treatment & Dose & Fall off time in second & 30 min \\
\cline { 3 - 5 } & & & $\mathbf{1 5}$ min & $48.80 \pm 0.917$ \\
\hline Control & Normal saline & $10 \mathrm{ml} / \mathrm{kg}$ & $51.80 \pm 1.020$ & $45.20 \pm 0.374$ \\
Standard & Lorazepam & $10 \mathrm{mg} / \mathrm{kg}$ & $6.80 \pm 0.374$ & $7.40 \pm 1.400$ \\
Extracts & 1)EEZO & $100 \mathrm{mg} / \mathrm{kg}$ & $8.80 \pm 0.374$ & $5.60 \pm 0.245$ \\
& 2) EEZO & $200 \mathrm{mg} / \mathrm{kg}$ & $3.40 \pm 0.245$ & $3.40 \pm 0.510$ \\
\hline
\end{tabular}

Each value $=$ mean \pm SEM for 5 mice; EEZO= Ethanolic Extract of Zingiber Officinale compared with control. Data were analysed by using Two-way ANOVA.

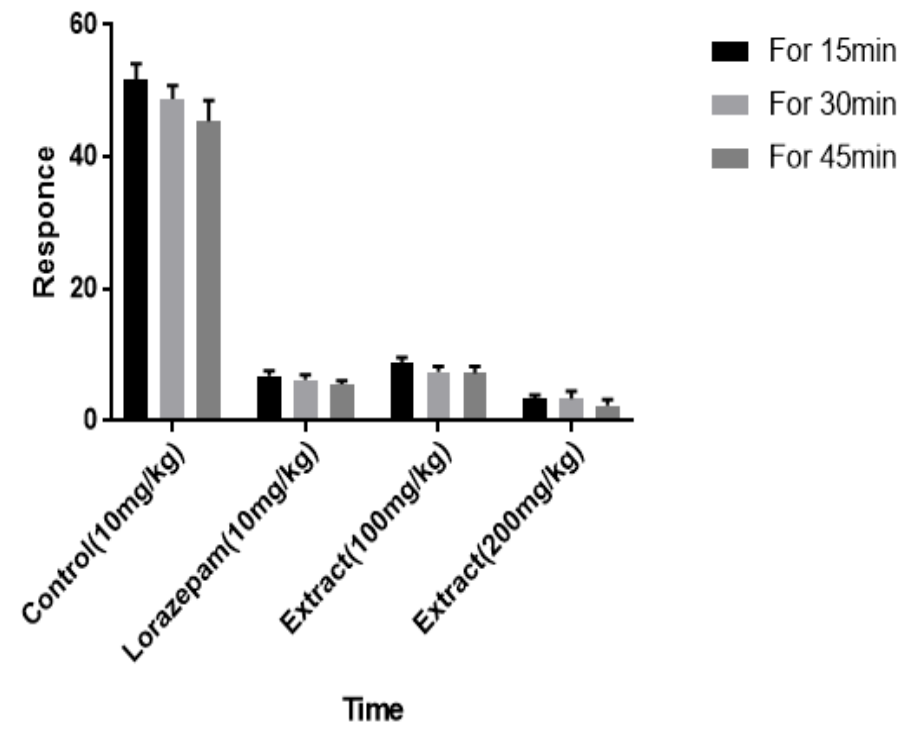

Fig. 1: Graph showing effect of EEZO by rota rod apparatus in mice (Conc. Vs. time)

\section{DISCUSSION}

Zingiberofficinale is a herbaceous perennial that has many medicinal uses which is helpful for a human being. It is having many phytochemical constituents and also have many pharmacological activities like anti-inflammatory, antioxidant, antimicrobial, antiemetic, antipyretic, analgesic, ant arthritic, anticancer activity etc.

To have a further descriptive knowledge regarding this plant, I have done phytochemical screening to check the presence of different phytochemical constituents and I found that it contains alkaloids, carbohydrate, phlobotannins, flavonoids, glycosides, saponins, tannin and terpenoids and absence of steroids.

The experiment was done on muscle relaxant activity of this plant in mice by using Rota-rod apparatus. In this experiment, the animals are divided into 4 groups containing 5 animals in each group. The first group serves as a control (normal saline), the second group serves as standard (Lorazepam) and the third and fourth group received extracts (EEZO) at a dose of $100 \mathrm{mg} / \mathrm{kg}$ and $200 \mathrm{mg} / \mathrm{kg}$ respectively. All the preparations are given orally. After the experiment was done, it shows that the fall of time in different time interval decreased according to the doses i.e. fall off time is Dose Dependent. The standard drug also showed a significant effect when compared with control.

The effect of EEZO at dose $200 \mathrm{mg} / \mathrm{kg}$ is found to be the highest. Therefore, it can be concluded that the ethanolic extract of the rhizome of Zingiberofficinale shows Muscle Relaxant Activity in dose dependent manner.

Therefore, from the above study, it is examined that Zingiberofficinale showing better pharmacological activities in dose dependent manner (muscle relaxant activity). Further studies may be performed on this herbal medicinal plant to know about the various effects, the potentiality of the plant and their role in curing various diseases.

\section{CONCLUSION}

In the present study, the various preliminary phytochemical tests, as well as Muscle Relaxant activity, was performed on the selected plant. This study shows that the rhizome of the plant Zingiberofficinale is having significant Muscle Relaxant activity and also justifies that the plant is used as an herbal remedy against many diseases.

Therefore, use of modern technology and further studies need to be done for the isolation and identification of the active principle which is responsible for these properties which can further gives rise to new drug molecule.

\section{CONFLICT OF INTERESTS}

\section{Declare none}

\section{REFERENCES}

1. Jafarikukhdan SH, Hosseini A, Armand R. The application of medicinal plants in traditional and modern medicine: a review of thymus vulgaris. Int J Clin Med 2015;6:635-42.

2. Ernst E. The efficacy of herbal medicine-an overview. Fund Clin Pharmacol 2005; 19:405-9.

3. Desousa A. Herbal medicines and anxiety disorders: an overview. 2013;1:18-23.

4. Zingiber officinale information from NPGS/GRIN", University of Maryland Medical Centre; 2006.

5. Shakya SR. Medicinal uses of ginger improves growth and enhances immunity in aquaculture. Int J Chem Stud 2015;3:83-6.

6. Ernst E, Pittler MH. Efficacy of ginger for nausea and vomiting: a systematic review of randomized clinical trials. $\mathrm{Br} \mathrm{J}$ Anesthesia 2000;84:367-71.

7. Bailey DN, Briggs JR. An unrecognized drug of abuse. Am J Clin Pathol 2002;117:396-400.

8. Shrestha BM. Muscle relaxant in $21^{\text {st }}$ century. Kathmandu University Med J 2003;1:60-4. 
9. Wallis TC. Textbook of Pharmacognosy, CBS Publishers and Distributors, New Delhi; 1985. p. 571-6.

10. Cartmell SM, Gelgor L, Mitchell D. A revised rota-rod procedure for measuring the effect of antinociceptive drugs on motor function in the rat. J Pharmacol Meth 1991;26:149-59.

\section{How to cite this article}

- Juri Das, Dipankar Saha. Preliminary phytochemical screening and evaluation of muscle relaxant activity of ethanolic extract of the rhizome of Zingiberofficinale. Int J Curr Pharm Res 2017;9(5):?? 